\title{
Analysis of environmental quality of pedestrian zones in Lithuanian cities
}

\author{
Rūta Dičiūnaitè-Rauktienė ${ }^{1}$, \\ Jolanta Valčiukiene $\dot{ }^{1}$, \\ Velta Paršova ${ }^{2}$, \\ Vida Maliené $\dot{1}^{1}$ \\ ${ }^{1}$ Aleksandras Stulginskis University, \\ 11 Studentu Street, \\ 53361 Akademija, Kaunas District \\ Email: diciunaite200@yahoo.com \\ ${ }^{2}$ Faculty of Environment and \\ Civil Engineering, \\ Latvia University of Agriculture, \\ 2 Liela Street, 3001 Jelgava, Latvia
}

\begin{abstract}
The rapidly growing level of urbanisation and automobilization in large cities as well as nearby towns, townships and villages increases the environmental pollution and noise that in turn negatively influence environmental quality and the health of residents. In order to reduce the negative influence on the environment especially in large cities, a great number of countries are planning to fully or partially stop using/restrict the use of vehicles in city centres by developing and creating pedestrian zones. Although pedestrian zones in large Lithuanian cities (Vilnius, Kaunas and Klaipeda) are partially isolated from vehicle traffic, the noise in such zones exceeds and the pollution reaches the highest permissible limits, which may be surpassed due to the increasing automobilization during rush hours or larger events. Having carried out the research, it was determined that it is vital to pay more attention to the factors of environmental protection, especially in the pedestrian zones located in Kaunas and Klaipeda cities. Therefore, in order to improve environmental quality based on the analysis of the current situation and the expert opinion, it is important to ban or partially restrict (at least on weekends) car traffic in adjacent streets as well as the pedestrian zones themselves.
\end{abstract}

Keywords: pedestrian zones, environmental quality, pollution, noise

\section{INTRODUCTION}

The increasing number of residents in large cities and frequently nearby towns, townships or villages results in the increased road traffic intensity which influences the growth of environmental pollution and noise, in turn worsening the climate and people's health in residential areas (Vardoulakis et al., 2015; Shathy, Reza, 2016). In order to stop the negative influence on environment, public health problems and taking into account social and economic issues, in 2001 the European Commission approved the Sustainable Development Strategy, that was renewed in 2006 and whose main goal is to stop climate change and its influence on the environment and society. Thus, all EU member-states are obliged to reduce the exhaust of greenhouse gas, protect public health and increase social inclusion, i.e. community spirit and citizenship, by 2020 (EU Council, 2006). The White Paper on Transport, approved by the European Commission on 28 March 2011, indicates that the EU member-states should halve the use of conventionally fuelled cars in urban transport by 2030 and phase them out in cities by 2050 . Based on the foregoing, a great number of cities are already planning to ban or partially restrict the use of private vehicles in the cities: 
Oslo is going to implement these measures by 2019, Madrid by 2020 and Hamburg by 2034 . Banning/restricting the use of cars in city centres is planned in other cities, including Paris, Helsinki, Brussels, Milan, Dublin and Kopenhagen (Nieuwenhuijsen, Khreis, 2016), therefore pedestrian zones are being created and developed (Mueller et al., 2016). The allocation of streets to pedestrians improves environmental quality (reduces noise, climate change, air pollution) (Pratt et al., 2012; Ferrer, Ruiz, 2017) and public health (related to the increased physical activity, i.e. walking, riding a bicycle, etc.) (Reiner et al., 2013; Gaskon et al., 2015; Nieuwenhuijsen, Khreis, 2016; Nieuwenhuijsen et al., 2016).

The development of pedestrian zones is mentioned in the National Progress Programme for Lithuania for the period 2014-2020 that indicates the importance of reducing air pollution by developing, improving/modernising public and bicycle transport infrastructure, pedestrian zones and public areas, thus encouraging and cultivating a healthy lifestyle to motivate economic growth and entrepreneurship (2014-2020 National Progress Programme for Lithuania). The National Strategy for Sustainable Development, that was renewed and approved on 16 September 2009, also states the importance of improving environmental quality, 'reducing the negative impact of vehicles on health and environment' (The National Strategy for Sustainable Development, 2010, p. 141).

Sustainable development is also mentioned in the Lithuanian Long-Term Development Strategy of the State. Although this document does not emphasise the importance of pedestrian zones, specifically such zones would help to implement some tasks indicated in the strategy, such as: to protect and foster cultural heritage providing possibilities for getting in touch with it; 'to expand possibilities for getting access to $\langle\ldots\rangle$ history, culture, art'. When it comes to environmental aspects, the document focuses on the importance of development, the rational use, protection and re-creation of natural, cultural heritage, biological diversity resources. Taking into consideration the EU requirements, the importance of improving environmental quality is also indicated. The creation of jobs and the increase of employment are mentioned as social aspects, while the promotion of entrepreneurship, tourism, small and medium- sized businesses is mentioned as an economic factor (Lithuanian Long-Term Development Strategy of the State, 2002). It is important to emphasize the fact that pedestrian zones motivate a healthy lifestyle (walking, riding a bicycle positively affect health), boosts the attractiveness of cities, encourages community spirit and protects environment (due to banned/restricted vehicle traffic). Furthermore, pedestrian zones also encourage economic growth and help preserve cultural heritage (Diciunaite-Rauktiene et al., 2018).

The aim of this article is to evaluate the environmental protection factors of the pedestrian zones in large Lithuanian cities and their significance.

Although the focal point of the article is the pedestrian zones of large Lithuanian cities, the research results may be topical to towns, townships and villages, especially those that are in close proximity to large cities, since currently Lithuania, as many other countries, faces quite an intensive development of suburban territories, characterised by the increase of the number of residents, built-up territories and road traffic intensity, which, as indicated before, influences the growth of environmental pollution and noise.

\section{METHODS AND CONDITIONS}

The research object is the pedestrian zones in the Lithuanian large cities - Vilnius, Kaunas and Klaipeda.

Kaunas city has two main pedestrian zones, namely Laisvès Avenue and the Old Town. Laisvès Avenue is connected to the main street of the Old Town, i.e. Vilnius Street, creating the longest pedestrian zone in the Eastern Europe (Andriukevičiūtè et al., 2015). The main pedestrian zones in Vilnius are Gediminas Avenue and the Old Town, while in Klaipeda the main pedestrian zone is the Old Town.

In order to determine the significance of the environmental protection factors of pedestrian zones situated in large Lithuanian cities in the period of September-October 2017, 140 experts, who were categorised into seven groups (20 experts in each group), i.e. environmentalists, territory planners, landscape architects, cultural heritage protection specialists, architects-urbanists, business people and economists, were surveyed. 
The respondents evaluated the significance of factors in the five-level Likert scale, where 1 is insignificant, 2 is partially insignificant, 3 is significant, 4 is very significant and 5 is exceptionally significant.

The data obtained during the research were calculated by using the Statistical Package for Social Sciences (SPSS) software. The following nonparametric research methods were applied:

- The Kruskal-Wallis test was applied to compare the ratio/interval and the ordinal variable in three or more independent samples;

- The Mann-Whitney test was used to determine the differences between two populations when the compared variable is either an ordinal or a ratio/interval, when the conditions of the use of a parametric factor are not fulfilled (this factor is analogous to the $t$-factor of independent samples).

- To determine the significance of the variable probability distribution between several dependent samples Friedman and Wilcoxon tests were used. The Wilcoxon test was applied to two independent samples taking into account the size and sign of the differences between two measurements. This factor is analogous to the MannWhitney factor for comparing two dependent samples. Therefore, in order to determine the difference of the significance of environmental, economic and social factors in main and Old Town pedestrian zones of different cities, Wilcoxon (when comparing the significance of factors in two cities or two zones) and Friedman (when comparing the significance of factors in three cities or zones) tests were used.

\section{RESULTS AND DISCUSSION}

Having surveyed 140 experts, it was determined that $99 \%$ of experts worked in their field of expertise, while their work time was categorised into the following groups by their expertise: $16 \%$ of experts had up to 5 years of experience, $44 \%$ from 5 to 10 years of experience, while the remaining $40 \%$ had more than 10 years of experience.

As stated by all the experts, environmental factors are highly important to pedestrian zones. However, having applied the Kruskal-Wallis test, it was determined that the evaluation of the significance of factors by the expert groups was different $(p<0.05)$. For instance, the importance of environmental protection factors for pedestrian zones received the highest evaluation by cultural heritage protection specialists and environmentalists (Table 1).

Table 1. The significance of environmental protection factors by expert groups

\begin{tabular}{c|c|c}
\hline \multirow{2}{*}{} & \multicolumn{2}{|c}{$\begin{array}{c}\text { Environmental protection } \\
\text { factors }\end{array}$} \\
\cline { 2 - 3 } & Average & \pm \\
\hline Environmentalists & 4.70 & 0.47 \\
\hline Territory planners & 3.85 & 0.81 \\
\hline Landscape architects & 4.20 & 0.77 \\
\hline $\begin{array}{c}\text { Cultural heritage pro- } \\
\text { tection specialists }\end{array}$ & 4.80 & 0.41 \\
\hline Architects-urbanists & 3.95 & 0.83 \\
\hline Business people & 4.25 & 0.79 \\
\hline Economists & 3.95 & 1.22 \\
\hline$H$ & \multicolumn{3}{|c}{$\mathbf{2 4 . 0 9 8}$} \\
\hline$d f$ & $\mathbf{6}$ \\
\hline$p$ & \multicolumn{3}{c}{$\mathbf{0 . 0 0 1}$} \\
\hline \multicolumn{3}{|c}{}
\end{tabular}

Having analysed the evaluations of experts working in their field of expertise and having applied the Kruskal-Wallis test, it was determined that there are no significant differences among the evaluations of experts $(p>0.05)$, which means that experts evaluated the significance of environmental factors irrespective of their work experience.

Having compared the evaluations of the significance of main pedestrian zones in Kaunas and Vilnius cities (Laisvès Avenue in Kaunas and Gediminas Avenue in Vilnius) (Table 2) and having applied the pair Wilcoxon test, it was determined that the experts found the clean environment of Gediminas Avenue and Laisvès Avenue more significant, however the evaluations of pedestrian zones did not differ significantly.

While having compared the Old Town zones in Vilnius, Kaunas and Klaipeda and having applied the Friedman test, it was determined that the evaluations of the pedestrian zones in these three Old Towns differ significantly in terms of noise (A1), air pollution (A2) and clean environment (A4) (Table 3).

As stated by the experts, all the environmental protection factors are more significant in the Klaipeda Old Town (including noise, 
Table 2. Differences in the significance of environmental protection factors between the main pedestrian zones in Laisvès Avenue in Kaunas and Gediminas Avenue in Vilnius

\begin{tabular}{|c|c|c|c|c|c|c|}
\hline & \multicolumn{6}{|c|}{ The main streets of the city } \\
\hline & \multicolumn{2}{|c|}{$\begin{array}{l}\text { Laisvès Avenue } \\
\text { in Kaunas }\end{array}$} & \multicolumn{2}{|c|}{$\begin{array}{l}\text { Gediminas Ave- } \\
\text { nue in Vilnius }\end{array}$} & \multirow{2}{*}{$Z$} & \multirow{2}{*}{$p$} \\
\hline & avg. & \pm & avg. & \pm & & \\
\hline A1: Noise: protected from noise produced by cars & 3.66 & 0.84 & 3.61 & 0.90 & -0.732 & 0.464 \\
\hline $\begin{array}{l}\text { A2: Air pollution: protected from pollution produced } \\
\text { by cars }\end{array}$ & 3.72 & 0.84 & 3.74 & 0.97 & -0.277 & 0.782 \\
\hline A3: The presence of trees and green zone & 3.52 & 1.25 & 3.81 & 0.99 & -1.951 & 0.051 \\
\hline $\begin{array}{l}\text { A4: Clean environment: recycle bins, clean streets and } \\
\text { sidewalks }\end{array}$ & 4.08 & 0.82 & 4.03 & 0.92 & -0.651 & 0.515 \\
\hline
\end{tabular}

pollution, presence of trees and green zones and clean environment). All the indicated factors are more significant in the pedestrian zones of Kaunas Old Town rather than in the pedestrian zones of Vilnius Old Town.
In order to determine what old towns were evaluated quite differently by experts, the Wilcoxon test was applied to the evaluations of the old towns in the three largest cities with a significant Kruskal-Wallis factor (Table 4).

Table 3. Differences in the significance of environmental protection factors between the main pedestrian zones in Kaunas, Vilnius and Klaipéda Old Towns

\begin{tabular}{|c|c|c|c|c|c|c|c|c|}
\hline & \multicolumn{8}{|c|}{ Old Town zones } \\
\hline & \multicolumn{2}{|c|}{ Kaunas } & \multicolumn{2}{|c|}{ Vilnius } & \multicolumn{2}{|c|}{ Klaipėda } & \multirow{2}{*}{$\mathbf{X}^{2}$} & \multirow{2}{*}{$p$} \\
\hline & avg. & \pm & avg. & \pm & avg. & \pm & & \\
\hline A1: Noise: protected from noise produced by cars & 3.64 & 0.93 & 3.55 & 0.84 & 3.91 & 0.84 & 16.443 & 0.000 \\
\hline $\begin{array}{l}\text { A2: Air pollution: protected from pollution } \\
\text { produced by cars }\end{array}$ & 3.69 & 0.97 & 3.55 & 0.86 & 3.95 & 0.82 & 18.968 & 0.000 \\
\hline A3: The presence of trees and green zone & 3.79 & 1.03 & 3.67 & 1.03 & 3.89 & 0.96 & 3.145 & 0.208 \\
\hline $\begin{array}{l}\text { A4: Clean environment: recycle bins, clean streets } \\
\text { and sidewalks }\end{array}$ & 4.01 & 0.87 & 3.68 & 1.03 & 4.12 & 0.82 & 15.276 & 0.000 \\
\hline
\end{tabular}

Table 4. Differences in the significance of environmental protection factors between the Old Town zones in different large cities

\begin{tabular}{|c|c|c|}
\hline Cities & Factor & Results of Wilcoxon test \\
\hline $\begin{array}{l}\text { More significant for Kaunas } \\
\text { than for Vilnius }\end{array}$ & $\begin{array}{l}\text { A4: Clean environment: recycle bins, clean streets } \\
\text { and sidewalks }\end{array}$ & $\begin{aligned} \mathrm{X}^{2}= & -3.326, p=0.001 \\
& (p<0.0 .05)\end{aligned}$ \\
\hline $\begin{array}{l}\text { More significant for Klaipeda } \\
\text { than for Vilnius }\end{array}$ & $\begin{array}{l}\text { A4: Clean environment: recycle bins, clean streets } \\
\text { and sidewalks }\end{array}$ & $\begin{aligned} \mathrm{X}^{2}= & -4.235, p=0.000 \\
& (p<0.0 .05)\end{aligned}$ \\
\hline $\begin{array}{l}\text { More significant for Klaipeda } \\
\text { than for Kaunas }\end{array}$ & A1: Noise: protected from noise produced by cars & $\begin{aligned} \mathrm{X}^{2}= & -2.892, p=0.004 \\
& (p<0.0 .05)\end{aligned}$ \\
\hline $\begin{array}{l}\text { More significant for Klaipèda } \\
\text { than for Vilnius }\end{array}$ & 1: Noise: protected from noise produced by cars & $\begin{aligned} \mathrm{X}^{2}= & -4.075, p=0.000 \\
& (p<0.0 .05)\end{aligned}$ \\
\hline
\end{tabular}


The presented results show that clean environment (A4) is least significant for the Vilnius Old Town zone, while the reduction of noise is significant for the Klaipeda Old Town.

Car traffic is the most dominant source of pollution and noise (Guerreiro et al., 2014). Although the main pedestrian zones of Lithuanian cities are partially isolated from traffic, in the Kaunas city pedestrian zones, i.e. Laisvès Avenue, some parts of the Old Town and the adjacent streets, the noise level is $65-70 \mathrm{dBA}$, whereas the level of $55 \mathrm{dBA}$ at daytime is considered to be above the limit (European Environment Agency, 2014) (Fig. 1).

The situation is similar in the Vilnius Old Town and Gediminas Avenue, except for the fact that here the noise level reaches 70-74 dBA not only in the adjacent streets, but also in Gediminas Avenue that is the main pedestrian zone of Vilnius. In the Klaipeda Old Town, the noise level in most streets reaches the limit of 65-69 dBA, and even exceeds $70-74 \mathrm{dBA}$ in the main roads (Fig. 2).

The analysis of the data on the level of air pollution in the pedestrian zones of Kaunas, Vilnius and Klaipeda provided by the Environmental Protection Agency showed that even though $\mathrm{NO}_{2}$ and benzo(a)pyrene air pollution did not exceed the limit, the highest permissible limit was reached. The fine particulate matter $\left(\mathrm{PM}_{10}\right.$ and PM 2.5) concentration reached the highest permissible limits in the pedestrian zones of Kaunas and Klaipeda. Meanwhile, in the Old Town of Vilnius, the average daily concentration of the particulate matter $\mathrm{PM}_{10}$ exceeded the daily limit value of 27 days a year in 2016 (Environmental Protection Agency).
The overview of the situation of the pedestrian zones of major Lithuanian cities requires a more detailed analysis. It can be argued that air pollution and noise produced by cars is a relevant issue not only in cities but also in pedestrian zones as noise produced by cars exceeds permissible limits, and increasing car pollution during rush hours or big events can also reach pedestrian zones, therefore it is necessary to take measures for the reduction of air pollution and noise, thus improving the overall environmental quality of the city. What is more, the level of automobilization keeps increasing, and even though there is no considerable air pollution in the analysed pedestrian zones (the maximum permissible limit is not yet exceeded but the rates are close to this limit), the problem may become very urgent. Taking into consideration the fact that air pollution may reach pedestrian zones from the adjacent streets, and that noise produced by cars exceeds the permissible limits, it would be expedient for municipalities of cities to consider restriction of car traffic or its full ban in the adjacent streets. Although this is not an easy decision and it is likely that there will be public dissatisfaction, car ban in the cities is being implemented in most countries (as mentioned before, in Oslo by 2019, in Madrid by 2020, in Hamburg by 2034 as well as similar initiatives in Brussels, Paris, Milan, Dublin, Helsinki, Copenhagen and many others). What is more, it is also important in the implementation of the White Paper on Transport that EU member-states should halve the use of conventionally fuelled cars in urban transport by 2030 and phase them out in cities by 2050 . Therefore, car traffic ban, or at least its partial limit (on weekends) in the adjacent and

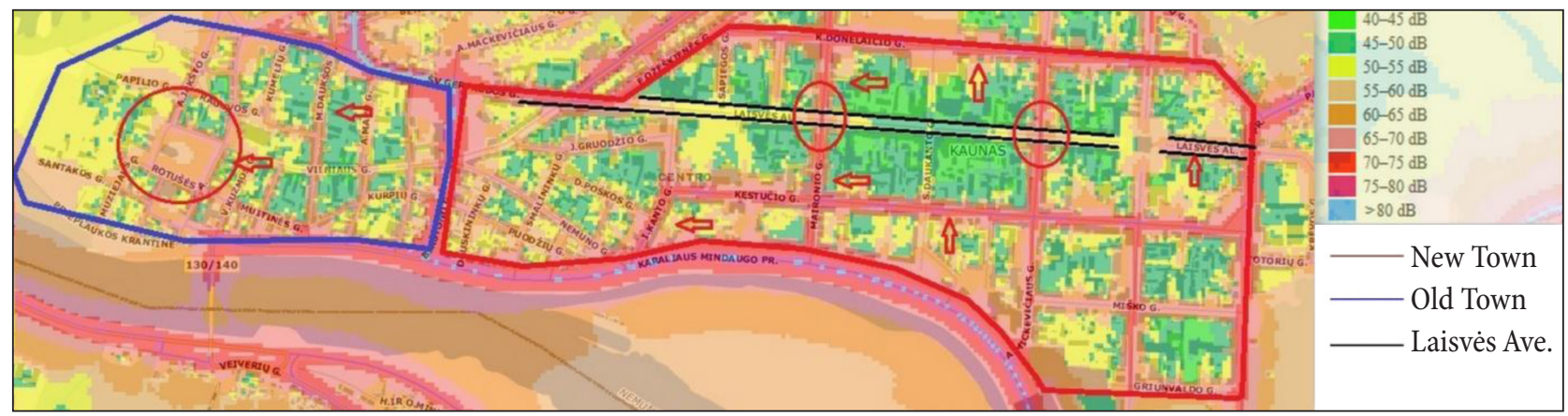

Fig. 1. Extract from the Kaunas City Strategic Noise Map 


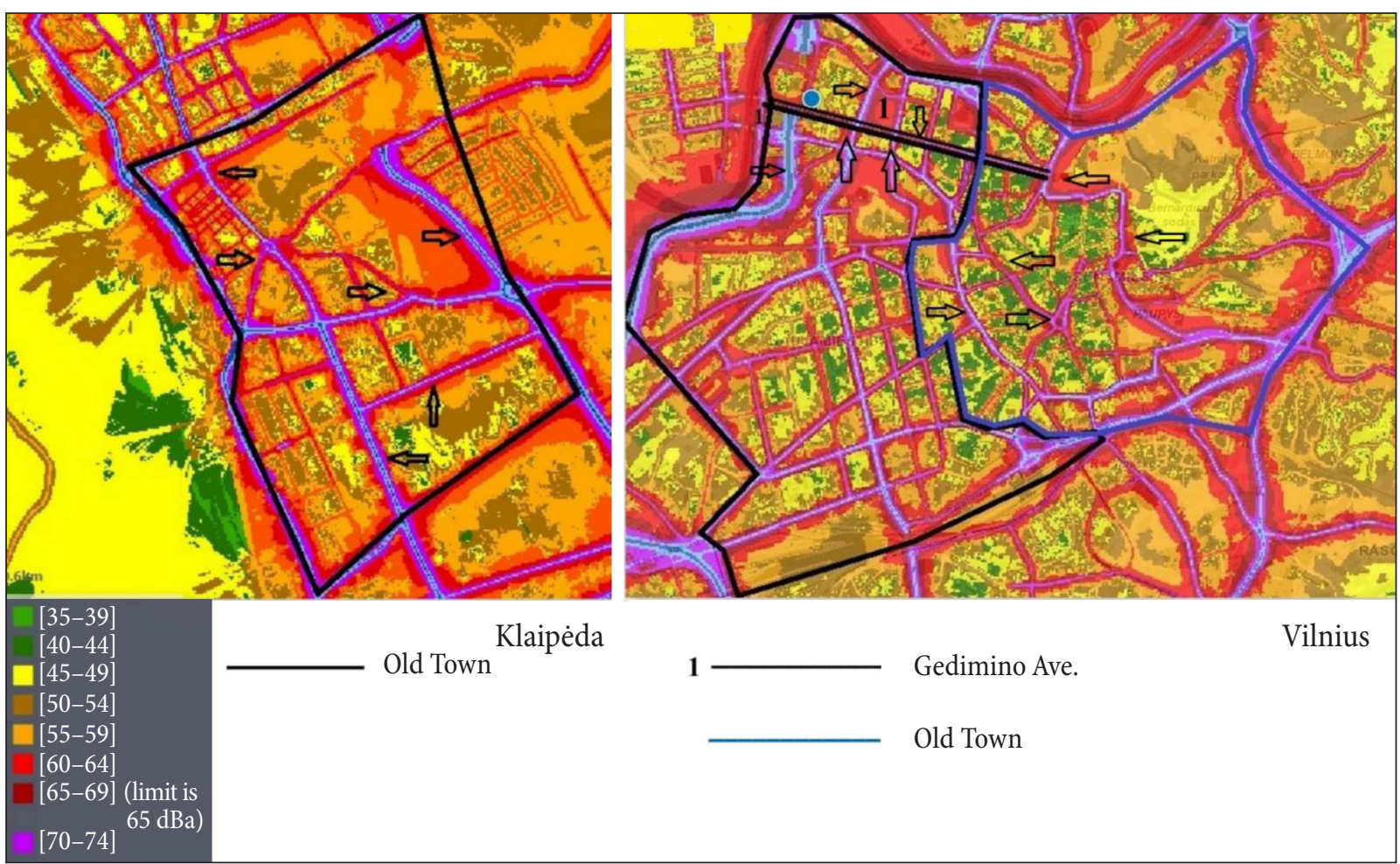

Fig. 2. Extract from Klaipeda and Vilnius city strategic noise maps

pedestrian areas would be a good starting point. The environmental quality would be improved as air pollution and noise would be reduced. This is confirmed by studies. For example, the car ban in New York and the use of the street for pedestrians resulted in a reduced level of NO pollution by $63 \%$, and $\mathrm{NO}_{2}$ pollution by $41 \%$ (The New York..., 2012). Restriction of car traffic on weekends resulted in a reduced level of nitrogen dioxide by $40 \%$ (Rojas-Rueda et al., 2012, 2013; Willsheras, 2015), black carbon concentration by 75-78\% (Invernizzi et al., 2011), and noise level by $10 \mathrm{~dB}$ (Brussels Environment, 2015). What is more, car ban/restriction does not only help to improve the quality of the environment, but also to protect the health of city residents.

If car traffic is restricted or banned, it is important to properly develop the accessibility of pedestrian zones by public transport. To reach this goal, it is important to draw attention to the data of urban residents survey, indicating the reasons why they do not use public transport. The Kaunas City General Plan states that the residents of Kaunas city evaluate public transport by 3.1 points (on a five-point scale), arguing that old vehicles cause a low driving quality and speed, and their schedule is not satisfactory (Kaunas City General Plan, 2013-2023). According to the data of the survey of Vilnius residents carried out on 22 May 2017, most residents of Vilnius (48.1\%) tend to use cars rather than public transport (only $22.1 \%$ of the respondents use it). In addition to this, the rates of walking, reaching destination by foot, have also decreased significantly. $26.3 \%$ of surveyed Vilnius residents claimed that they were not satisfied with public transport because it is uncomfortable and slow, although even $76.5 \%$ of respondents believe that the quality of public transport services has improved within 5 years. In general, only $27 \%$ of respondents are satisfied with the quality of public transport services. The review of sustainable urban mobility planning in Klaipeda city (2017) indicated that according to the survey of Klaipeda city residents carried out in May-June of 2017, the quality of public transport was rated by 3.69 points (on a five-point scale). It was found that $35 \%$ of residents prefer cars, $29 \%$ prefer reaching destination on foot and the same number of residents (29\%) choose public transport, while bike as a means of transport is preferred by $4 \%$. During all surveys respondents indicated that the use 
of public transport would be encouraged by a more frequent schedule, more affordable prices and a better accessibility of stops.

\section{CONCLUSIONS}

All the environmental protection factors, i.e. air pollution, clean environment, presence of green zones and trees, are exceptionally important to the pedestrian zones, however the separate evaluation of the significance of each environmental protection factor differs slightly. The experts believe that clean environment is more significant to the pedestrian zones in Kaunas Laisvès Avenue and Vilnius Gediminas Avenue. While such environmental protection factors as clean environment, noise and pollution caused by cars as well as the presence of green zones and trees are equally significant to the pedestrian zones in the Klaipeda and Kaunas Old Towns.

The analysis of the current situation of environmental factors, namely vehicle noise and pollution, indicated that it is important to pay a great attention to the improvement of environmental quality in the pedestrian zones of large Lithuanian cities, since in the pedestrian zones of Kaunas city, such as Laisvès Avenue and some places of the Old Town, the noise level reaches 65-70 dBA, in the Vilnius Old Town and Gediminas Avenue the noise level even reaches 70-74 dBA not only in adjacent streets but also in Gediminas Avenue, which is the main pedestrian zone in Vilnius city, and in the majority of Klaipeda Old Town streets the noise level reaches 65-69 dBA, and even 70$74 \mathrm{dBA}$ by the main roads.

Air pollution $\left(\mathrm{NO}_{2}\right.$, benzo(a)pyrene, particulate matter) in the Kaunas, Vilnius and Klaipeda pedestrian zones does not exceed permissible limits, however the highest permissible limit is reached. The fine particulate matter $\left(\mathrm{PM}_{10}\right.$ and PM 2.5) concentration also reached the highest permissible limits in the Kaunas and Klaipeda pedestrian zones. Meanwhile, in the Old Town of Vilnius, the average daily concentration of the particulate matter $\mathrm{PM}_{10}$ exceeded the daily limit value of 27 days a year in 2016 .

Therefore, in order to improve environmental quality based on the analysis of the current situation and the expert opinion, it is important to ban or partially restrict (at least on weekends) car traffic in adjacent streets as well as the pedestrian zones themselves.

Received 2 May 2018

Accepted 22 June 2018

\section{REFERENCES}

1. Air Pollution Maps. Environmental Protection Agency [cited 2018-04-23]. Available at: http:// oras.gamta.lt $/ \mathrm{cms} /$ index? rubricId $=45 \mathrm{be} 1152-1 \mathrm{e} 5 \mathrm{a}-$ 4162-a612-e03ba819de98

2. Andriukevičiūtė J., Martišiūtė J., Kandrotienè D. 2015. Lithuania Travel Guide. Vilnius, Lithuania: Terra Publica. $256 \mathrm{p}$.

3. Brussels Environment. 2015 [cited 2018-04-18]. Available at: http://www.environment.brussels/ state-environment/summary-report-2011-2012/ noise/focus-acoustic-evaluation-car-free-sundayaction/

4. Diciunaite-Rauktiene R., Gurskiene V., Burinskiene M., Maliene V. 2018. The usage and perception of pedestrian zones in Lithuanian cities: multiple criteria and comparative analysis. Sustainability. No. 10. P. 1-22.

5. European Council [cited 2018-04-22]. Available at: http://www.europarl.europa.eu/atyourservice/lt/ displayFtu.html?ftuId=FTU_5.4.5.html

6. European Environment Agency. 2014. Noise in Europe 2014 [cited 2018-04-22]. Available at: https://www.eea.europa.eu/publications/noise-ineurope-2014/file

7. Ferrer S., Ruiz T. 2017. The impact of the built environment on the decision to walk for short trips: Evidence from two Spanish cities. Transport Policy [cited 2018-04-22]. Available at: https://doi. org/10.1016/j.tranpol.2017.04.009

8. Gascon M., Triguero-Mas M., Martínez D., Dadvand P., Forns J., Plasència A., Nieuwenhuijsen M. J. 2015. Mental health benefits of longterm exposure to residential green and blue spaces: a systematic review. International Journal of Environmental Research and Public Health. Vol. 12. P. 4354-4379.

9. Guerrero L. A., Maas G., Hogland W. 2013. Solid waste management challenges for cities in developing countries. Waste Management. Vol. 33. P. $220-232$.

10. Invernizzi G., Ruprecht A., Mazza R., De Marco C., Mocnik G., Sioutas C., Westerdahl D. 2011. Measurement of black carbon concentration as an indicator of air quality benefits of traffic restriction policies within the ecopass zone in Milan, Italy. Atmospheric Environment. No. 45. P. 3522-3527.

11. Kaunas City General Plan 2013-2023 [cited 2018-0423]. Available at: http://www.kaunas.lt/wp-content/ uploads/sites/8/2015/06/aiskinamasis-rastas.pdf 
12. Lithuanian Long-Term Development Strategy of the State. 2002 [cited 2018-04-23]. Available at: https://www.e-tar.lt/portal/lt/legalAct/TAR. 455D7C22A4D9

13. Mueller N., Rojas-Rueda D., Cole-Hunter T., de Nazelle A., Dons E., Gerike R., Götschi T., Panis L. I., Kahlmeier S., Nieuwenhuijsen M. 2015. Health impact assessment of active transportation: a systematic review. Preventive Medicine. Vol. 76. P. 103-114.

14. 2014-2020 National Progress Programme for Lithuania [cited 2018-04-23]. Available at: https://www.e-tar.lt/portal/lt/legalAct/TAR.31A566 B1512D

15. Nieuwenhuijsen M. J., Khreis H. 2016. Car free cities: Pathway to healthy urban living. Environment International. Vol. 94. P. 251-262.

16. Nieuwenhuijsen M. J., Khreis H., Verlinghier E., Rojas-Rueda D. 2016. Transport and health: a marriage of convenience or an absolute necessity. Environment International. Vol. 88. P. 150-152.

17. Noise Map of Kaunas City. 2017 [cited 2018-0423]. Available at: http://infr.kaunas.lt/noise\#roads_ day_2017

18. Noise Map of Klaipeda City. 2017. [cited 201804-23]. Available at: http://www.geoportal.lt/ savivaldybes/klaipeda

19. Pratt M., Sarmiento O. L., Montes F., Ogilvie D., Marcus B. H., Perez L. G., Brownson R. C. 2012. The implications of megatrends in information and communication technology and transportation for changes in global physical activity. Lancet. Vol. 380. No. 9838. P. 282-293.

20. Reiner M., Niermann C., Jekauc D., Woll A. 2013. Long-term health benefits of physical activity - a systematic review of longitudinal studies. BMC Public Health. Vol. 813. No. 13. P. 1-9.

21. Rojas-Rueda D., de Nazelle A., Teixidó O., Nieuwenhuijsen M. J. 2012. Replacing car trips by increasing bike and public transport in the greater Barcelona metropolitan area: a health impact assessment study. Environment International. Vol. 49. P. 100-109.

22. Rojas-Rueda D., de Nazelle A., Teixidó O., Nieuwenhuijsen M. 2013. Health impact assessment of increasing public transport and cycling use in Barcelona: a morbidity and burden of disease approach. Preventive Medicine. Vol. 57. No. 5. P. 573579.

23. Shathy S. T., Reza M. I. H. 2016. Sustainable cities: A proposed Environmental Integrity Index (EII) for decision making. Frontiers in Environmental Science. Vol. 4. P. 1-12.

24. The National Strategy for Sustainable Development. 2010 [cited 2018-04-23]. Available at: https://www.e-
tar.lt/portal/lt/legalAct/TAR.EAC62D7F8C15/ TAIS_396083

25. The New York City Department of Health and Mental Hygiene (NYC DOHMH). 2012. Mayor Bloomberg Announces Latest Results of Health Department Air Quality Study That Shows Air in Times Square is Cleaner and Healthier Since Pedestrian Plazas Were Opened [cited 2018-0423]. Available at: http://www1.nyc.gov/office-ofthe-mayor/news/120-11/mayor-bloomberg-latestresults-health-department-air-quality-studyshows-air-in

26. Vardoulakis S., Dimitroulopoulou C., Thornes J., Lai K. M., Taylor J., Myers I., Heaviside C., Mavrogianni A., Shrubsole C., Chalabi Z., Davies M., Wilkinson P. 2015. Impact of climate change on the domestic indoor environment and associated health risks in the UK. Environment International. Vol. 85. P. 299-313.

27. Vilnius Noise Data. 2017 [cited 2018-04-23]. Available at: http://aplinka.vilnius.lt/triuksmas/

28. Willsher K. 2015. Paris's First Attempt at Car-free Day Brings Big Drop in Air and Noise Pollution [cited 2018-04-24]. Available at: http://www.theguardian.com/world/2015/oct/03/pariss-firstattempt-at-car-free-day-brings-big-drop-in-airand-noise-pollution

\section{Rūta Dičiūnaitè-Rauktienė, Jolanta Valčiukienė, Velta Paršova, Vida Malienė}

\section{PĖSČIŲJŲ ZONŲ APLINKOS KOKYBĖS ANALIZĖ LIETUVOS MIESTUOSE}

Santrauka

Sparčiai augant urbanizacijos lygiui, automobilizacijai, didèja ir aplinkos tarša bei triukšmas. Tai neigiamai veikia aplinkos kokybę ir gyventojų sveikatą. Siekdamos sumažinti neigiamą poveikị aplinkai, nemažai šalių planuoja visiškai arba iš dalies atsisakyti / riboti transporto priemonių eismą miesto centruose, plèsti ir kurti pėsčiųjų zonas. Lietuvos didžiuosiuose miestuose (Vilniuje, Kaune ir Klaipėdoje) nors pèsčiųjų zonos iš dalies atribotos nuo transporto eismo, tačiau jose triukšmas viršija, o tarša siekia aukščiausią leistiną normą, kuri sparčiai augant automobilizacijai, ypač piko ar didesnių renginių metu, gali viršyti leistinas normas. Nustatyta, kad ypač Kauno ir Klaipėdos miestų pėsčiųjų zonose svarbu skirti daugiau dėmesio aplinkosaugai. Atsižvelgiant ị esamos padèties analizę ir ekspertų nuomonę, svarbu uždrausti arba bent riboti (pvz., savaitgaliais) automobilių eismą šalia pėsčiųjų zonų esančiose gatvėse.

Raktažodžiai: pėsčiųjų zonos, aplinkos kokybè, tarša, triukšmas 